KEY TO THE SPECIES OF LEPTOGLOSSUS GUER. OCCURRING NORTH OF MEXICO (HETEROPTERA; COREID $Æ$ ).

\author{
By Edmund H. Gibson, \\ Bureau of Entomology, Washington, D. C.
}

The cosmopolitan genus Leptoglossus Guér. is represented in America, north of Mexico, by nine species all of which are listed in Van Duzee's recent check list. Specimens bearing labels of two other species, namely balteatus Linn. and stigma var. minor Dall. are in the collection of the U. S. National Museum, but I believe them to have been wrongly determined.

This genus belongs to the tribe Anisoscelini A. \& S. and may be separated from Chondrocera Lap. and Narnia Stal, the other two genera of the tribe which are known to occur in North America, by the large dilations of the hind tibiæ and simple antennæ which have their basal joint long.

In working out the key to the species, color markings have been eliminated as far as possible. Specimens of each species have been examined and in practically each one access has been had to large series, which are in the collection of the U. S. National Museum.

\title{
Leptoglossus Guér.
}

Leptoglossus Guér., Voy. de la Coquille, Ins., p. 174, 1838.

Anisoscelis .Spin., Ess. Hem., p. 200, 1837.

Theognis Stal, Stettiner, Ent. Zeitg., xxiii, p. 294, 1862.

Leptoglossus Guér. may be characterized as follows: Head elongate, horizontal. Antennæ rather stout but not swollen or dilated, basal joint long, about equal to length of the head; rostrum passing the metasternum; bucculæ short. Thorax longer than head, broad and rounding posteriorly. Elytra narrowing towards apex. Hind femora more or less swollen; hind tibiæ with large dilations of foliations, the outer margins of which are usually more or less deeply scalloped. Spiracles at base and apex of abdomen about equally remote.

The haplotype of the genus is dilaticollis Guér. 
Key to the species of Leptoglossus occurring north of Mexico.

1. Thorax coarsely punctate or rugose.......fulvicornis Westw. Thorax not rugose, only finely punctate............2

2. Apex of head terminating in a stout spine.....clypealis Heid. Apex of head without a spine. . . . . . . . . . . . . . . ...

3. Fourth joint of the antennæ equal to or shorter than the third joint. . . . . ..........................4

Fourth joint of antennæ longer than third joint. . . . . . .

4. The outer expansion of the hind tibiæ reaching almost to apex of tibiæ, lanceolate...........................

The outer expansion of the hind tibiæ reaching but two thirds the length of tibiæ, foliaceous..........occidentalis Heid.

5. Lateral-posterior margins of thorax more or less crenulate . . . .6

Lateral-posterior margins of thorax not crenulate, and with only a mere trace of a transverse color band or line on the elytra........................................ Say

6. Posterior angle of thorax terminating in a prominent spine

gonagra Fabr.

Posterior angles of thorax not terminating in a prominent spine..............................

7. Thorax bordered with bright orange and foliation of hind tibiæ

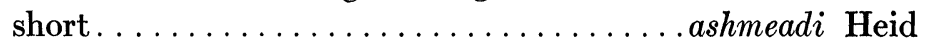

Thorax not bordered with orange. Foliation of hind tibiæ large and long. . . . . . . . . . . . . . . . 8

8. Scallops in the foliations of the hind tibiæ deep and long. Posterior femora prominently incrassated.......zonatus Dall.

Scallops in the foliation of hind tibiæ shallow and usually short. Posterior femora swollen but not prominently incrassated phyllopus Linn.

Leptoglossus fulvicornis Westw.

Leptoglossus fulvicornis Westw., Hope Cat., 11, p. 17, 1842.

Leptoglossus magnoliæ Heid., Pro. Ent. Soc. Washington, xii, 1910, p. 191.

This is a large species and can be distinguished from all others by having the thorax coarsely punctate or rugose. Antennæ and first two pairs of legs light in color. No band or markings on elytra. Posterior angles of thorax broadly rounded and prominently raised. 
It ranges from Maryland southward through Florida and Alabama.

\section{Leptoglossus clypealis Heid.}

Leptoglossus clypealis Heid., Pro. Ent. Soc. Washington, xii, p. $195,1910$.

The apex of the head terminating in a spine is the character which readily distinguishes this species from all others of the genus.

This is a western species occurring from Nebraska to Oregon, south through California, Arizona and New Mexico.

\section{Leptoglossus corculus Say.}

Anisoscelis corculus Say, Ent. of N. A., Vol. 1, p. 326, 1832.

Theognis excellens Mayr, Verh. Zoöl.-bot. Ges. Wein., xv, p. 434, 1865.

Together with the following species corculus has the fourth joint of the antennæ equal to or shorter than the third. This character may be used to separate these two species. Corculus differs markedly from occidentalis in having the dilation of the hind tibiæ lanceolate and reaching nearly to the apex of the tibiæ, while the dilation in occidentalis is foliaceous and much shorter.

It is known to occur from New Jersey southward through Georgia, and west to Colorado.

\section{Leptoglossus occidentalis Heid.}

Leptoglossus occidentalis Heid., Pro. Ent. Soc. Washington, xii, p. 196, 1910.

Following his description of the species Mr. Heidemann states: “This species has frequently been determined as $L$. corculus Saybut by close observation the differently shaped expansion of the hind tibiæ will distinguish it at once." The expansion is shorter and foliaceous.

The known distribution is from Colorado west to the coast and from California north to Vancouver.

\section{Leptoglossus oppositus Say.}

Anisoscelis oppositus Say, Ent. of N. A., Vol. 1, p. 326, 1832.

Anisoscelis tibialis H. S., Wanz. Ins., Vol. 7, p. 12, 1844.

The distinguishing characters for this species are the smooth lateral-posterior margins of the thorax and the unmarked elytra. 
Only occasionally is there a faint transverse line on the elytra. The foliations of the hind tibiæ are large with deep scallops.

This is probably the most common species in the United States. It is primarily a southern species but is known to occur as far north as New Jersey.

\section{Leptoglossus gonagra Fabr.}

Cimex gonagra Fabr., Syst. Ent., p. 708, 1775.

Cimex grallator Herbst., Gem. Naturg., vi, p. 239, 1784.

Anisoscelis antica H. S., Wanz. Ins., iii, p. 92, 1835.

Anisoscelis præcipua Walk., Cat. Hem. Het. British Mus., p. 128, iv, 1871.

This is a large species and easily recognizable by the broad thorax, the lateral-posterior angles of which terminate in a prominent spine, and also by the yellow transverse curved line on the anterior portion of the thorax. It is strictly a southern species.

\section{Leptoglossus ashmeadi Heid.}

Leptoglossus ashmeadi Heid.. Bul. Buffalo Soc. Nat. Sci., ix, p. 237, 1909.

Of the species occurring north of Mexico this is the most easily recognized one. The exceptionally short foliation of the hind tibiæ and the bright orange coloration on the head and thorax make the identity unmistakable. Mr. Heidemann recorded it only from Florida.

\section{Leptoglossus zonatus Dall.}

Anisoscelis zonatus Dallas, List. Hem. Brit. Mus., ii, 1852.

Closely related to phyllopus Linn. but from which it can be separated by having the scallops of the foliations of the hind tibix deeper and longer. A comparatively large species and recorded only from the south.

\section{Leptoglossus phyllopus Linn.}

Cimex phyllopus Linn., Syst. Nat., 1, 2, p. 731, 1767.

Anisoscelis albicinctus Say, Ent. of N. A., Vol. 1, p. 326, 1832.

Anisoscelis fraternus Westw., Hope Cat., ii, p. 16, 1842.

Anisoscelis confusus Dallas, List Hem. British Mus., ii, p. 453, 1852.

With oppositus Say this is one of the two most common species in the United States. It can be distinguished, however, from 
oppositus by having the lateral-posterior margins of the thorax crenulated and by the prominent yellow band across the elytra. In general form it is nearest to zonatus Dall. but the latter has a much larger hind femora while the femora of phyllopus is only normally swollen. The scallops in the foliation of the hind tibiæ are rather shallow and much shorter than in zonatus. Specimens have been examined from Virginia south to Florida and Texas.

THE LIFE-HISTORY OF MESOVELIA MULSANTI WHITE.

By H. B. Hungerford, Cornell University, Ithaca, N. Y.

Among the most familiar inhabitants upon the surface of our ponds and quiet pools are the "skaters." These long-legged creatures that deport themselves with such ease and agility upon the surface of the waters have been noted by even the most casual observers. Their size and movements have forced at least a passing notice, but there are a number of small related species that escape all but those who look intently. Among these smaller forms is the little green Mesovelia mulsanti. It wears the brightest livery of them all, for the young and the apterous forms of the adults display varying degrees of green coloration, while the winged ones are even more conspicuous on the floating blankets of green algæ because of the silvery whiteness of their wings.

These insects measure only from four to five millimeters in length but are so distinct from other bugs in structure that they have been regarded as a distinct family.

At various times in the past they have been found in our collections associated with the Hebrido, Gerrido, Hydrometridoe and Veliido but at last have been segregated as the family Mesoveliidoe. The species here treated is the only one reported from the United States, but it is a widely distributed form.

It is at home in the haunts of the marsh-treader on the floating vegetation growing in the shallow waters of the pools, where the clumps of sedge spread their slender stems upon the water from the bordering bank, where young cat-tails spring up and green algæ carpet the surface of the waters. 

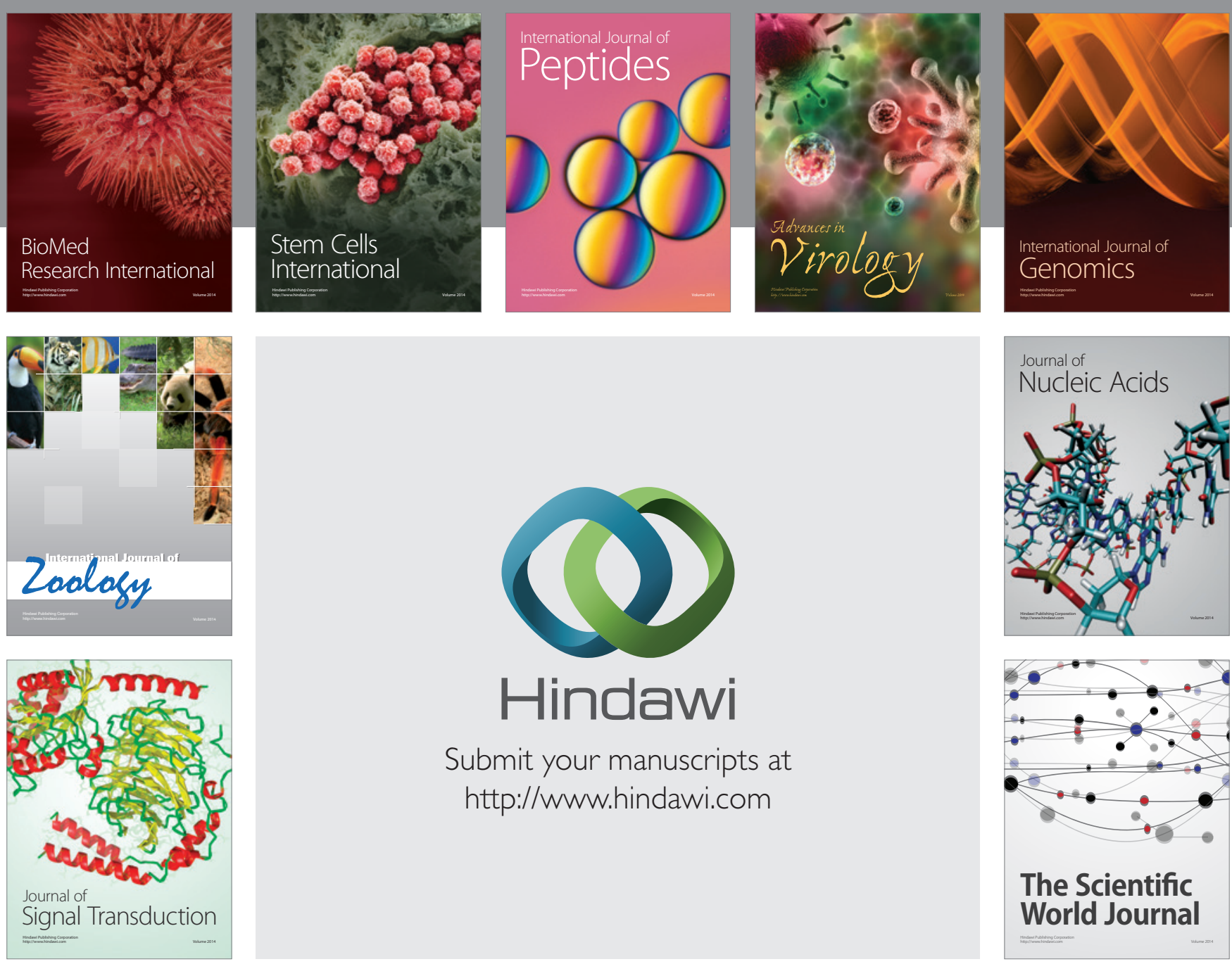

Submit your manuscripts at

http://www.hindawi.com
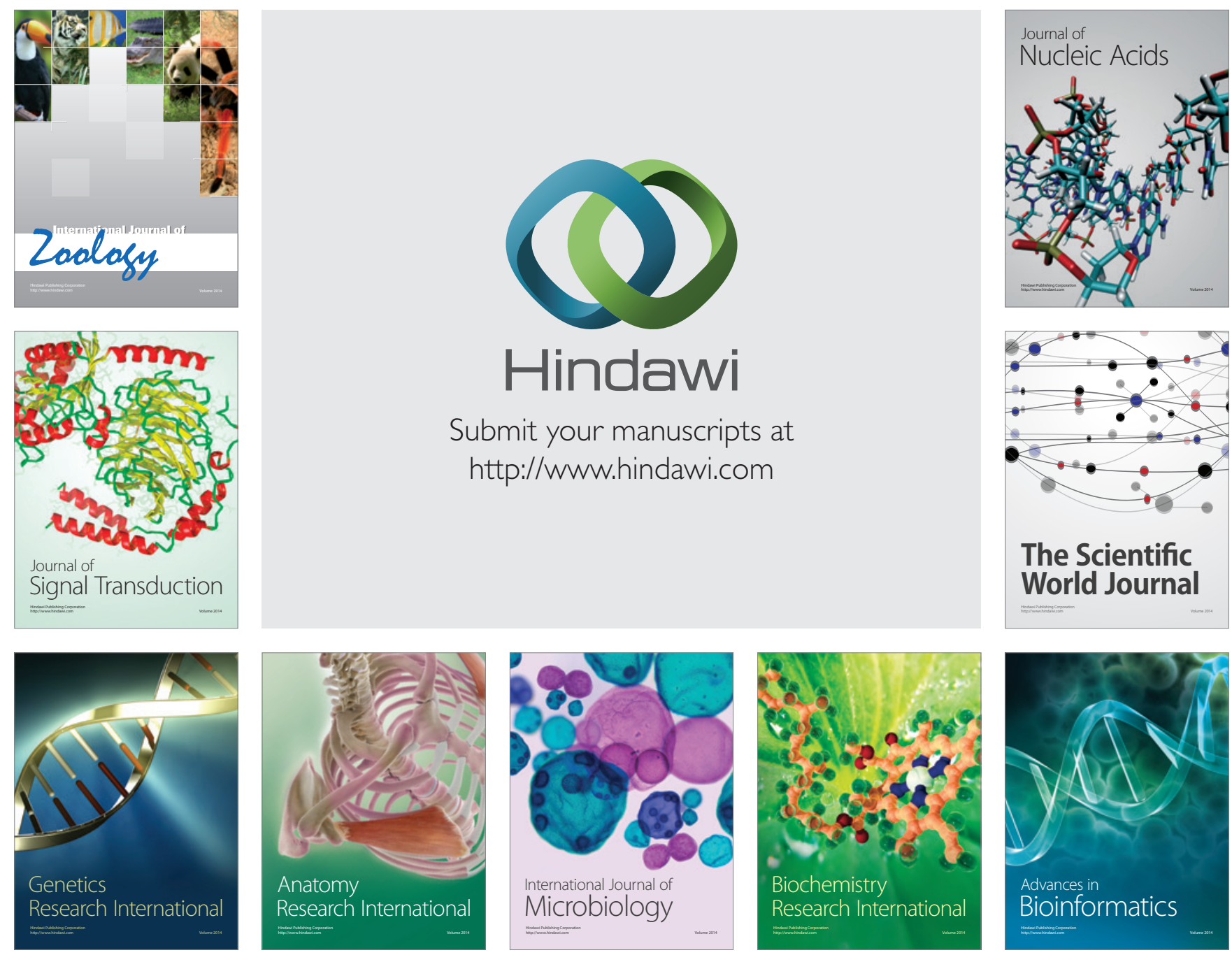

The Scientific World Journal
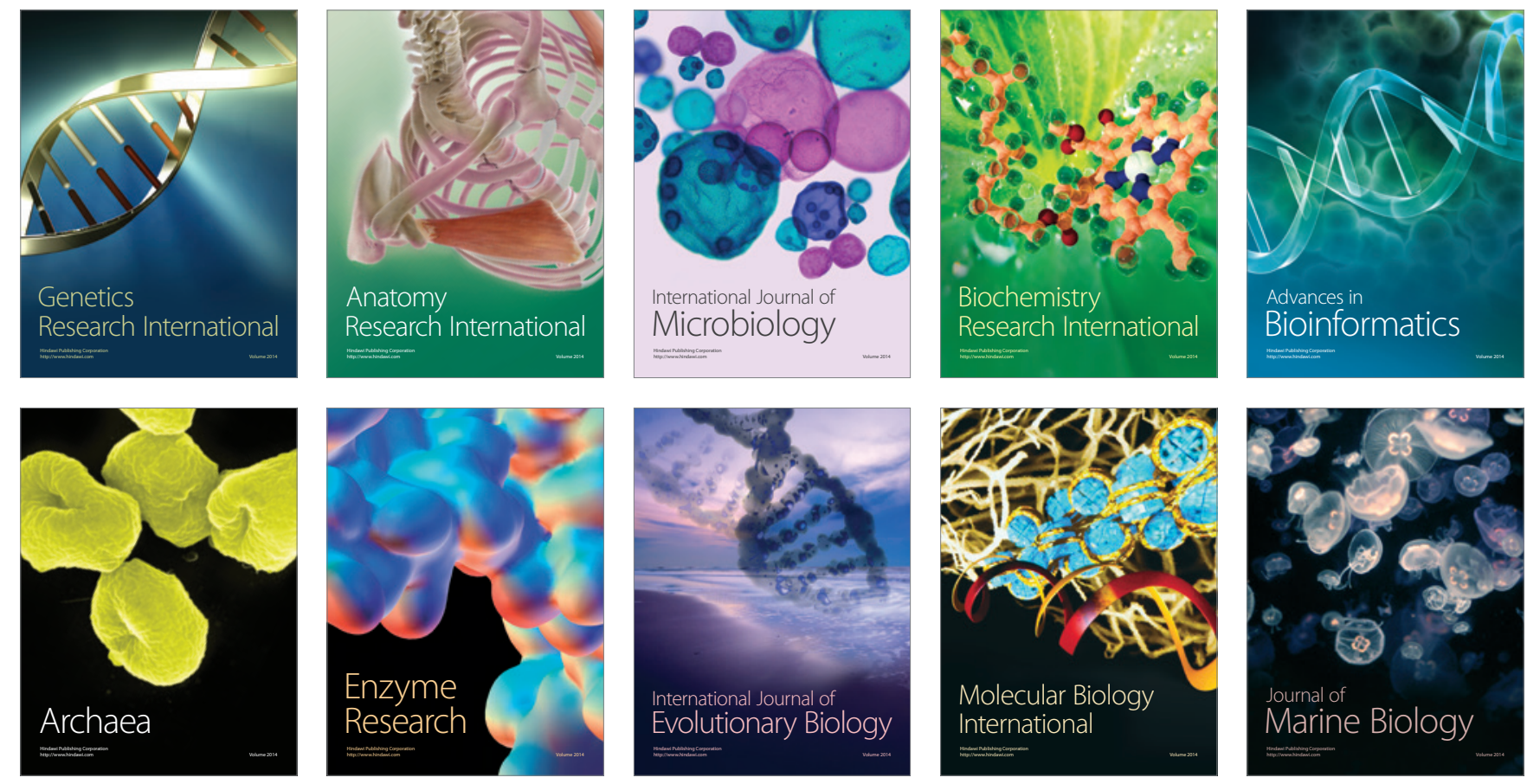